\title{
Rancang Bangun Kombinasi Trafo 1 Ampere CT dan 5 Ampere Engkel Untuk Efisiensi Power Amplifier Class GB (Groudbridge)
}

\author{
Arief Budi Laksono \\ Program Studi Jurusan Teknik Elektro, \\ Fakultas Teknik, Universitas Islam Lamongan \\ email : ariefbudila@gmail.com
}

\begin{abstract}
ABSTRAK
Seiring dengan berkembangnya teknologi tentang audio soundsystem maka inovasi serta rancangan-rancangan baru tentang audio sangatlah banyak, musik merupakan suatu hiburan yang hampir setiap hari ditemui oleh masyarakat saat ini, Produk-produk amplifier yang umum dipasaran (produk jadi) masih sangat didominasi oleh pasaran luar negeri. Power amplifier class GB (Ground Bridge) merupakan salah satu jenis poweramplifier yang membutuhkan tegangan input yang tinggi dalam dunia audio, penggunaan kombinasi trafo yang sesuai dan dengan pengambilan tegangan output trafo yang pas sudah mampu memenuhi kapasitas daya yang dibutuhkan untuk amplifier tersebut tanpa harus mencari jenis trafo dengan spesifikasi voltoutput yang tinggi. Jadi pemilihan komponen yang baik bisa menjadikan kinerja power amplifier ini menjadi maksimal.
\end{abstract}

Kata kunci : Tegangan, Kombinasi, Trafo

\section{PENDAHULUAN}

Seiring dengan berkembangnya teknologi tentang audio sound sistem maka inovasi serta rancangan-rancangan baru tentang audio sangatlah banyak, musik merupakan suatu hiburan yang hampir setiap hari di temui oleh masyarakat saat ini, pesat teknologi yang berkembang saat ini seperti gadget smartphone yang informasi seperti musik dan lain lain yang berhubungan dengan audio sangat banyak diburu oleh masyarakat modern saat ini.

Produk produk amplifier yang umum dipasaran (produk jadi) masih sangat didominasi oleh pasaran luar negeri, oleh karena itu pembangunan sistem audio di indonesia juga harus mampu bersaing dengan produk produk dari luar.Permasalahan yang ada. Yakni Bagaimana desain rangkaian power supplay yang digunakan, Bagaimana sistem kerja trafo yang digunakan, Bagaimana efisiensi power amplifier class $G B$ yang dikombinasikan dengan dua trafo tersebut

Manfaat yang di dapat dari penelitian ini adalah Mengetahui efisiensi power amplifier class GB (Ground Bridge) apabila di bandingkan dengan poweramplifierclass lain serta untuk mengetahui apakah power tersebut mampu bekerja maksimal apabiladisandingkan dengan power class lain disuatu event yang menggunakan audio.

\author{
METODOLOGI PENELITIAN \\ Alat dan Bahan \\ - Trafo CT 1 ampere \\ - Trafo Engkel 5 ampere \\ - Power supply \\ - Amplifier \\ - dB meter (android)
}

\section{Metodologi}

Melakukan eksperimen penggunaan trafo ct 1 ampere dan trafo 5 ampere sebagai sumber daya dari power amplifier dan mengamati karakteristik kualitas suara dan juga daya outputnya.

\section{Metode Analisis Data}

Analisis data menggunakan hasil pengukuran output baik daya dan kualitas suara dari perbandingan penggunaan trafo CT 1 ampere tanpa digabung dan penggunaan trafo CT 1 ampere yang digabung trafo 5 ampere sebagai suplay power amplifier .

\section{HASIL DAN PEMBAHASAN}

Berikut merupakan hasil penelitian dari kombinasi trafo 1 ampere ct dan 5 ampere engkel yang digunakan untuk mensuplai modifikasi power amplifier yang dilakukan agar lebih efisien hasil keluarannya. 


\section{Cara kerja power amplifier}

Mengacu pada rangkaian dasar power amplifier class $G B$ dimana dari dua rangkaian tersebut mengeluarkan dua output namun output yang satunya merupakan ground aktif, prinsip kerjanya memang hampir sama dengan skema power BTL.

Tetapi sumber catu tegangan yang dipakai power amplifier BTL hanya memakai tegangan sumber travo $C T$ (center tab). Power amplifier ground bridge ini mengombinasii 2 travo, Merupakan paduan travo 5amper engkel dan travo lamper $c t$, sedangkan travo ctmensupply tegangan pada driverconveor pada sistem osilator IC ( pengutan awalan dari buffer transistor amplifier), karena adanya signal yang cukup kuat menghendel beberapa transistor tingkatan penguatan, tegangan travo $c t$ menggunakan tegangan output $15 \mathrm{vcd}$, yang membangun kinerja osilator yang cukup kuat untuk mengerjakan 2 jenis power amplifier yang berbeda sistem dijadikan kombinasi 1, ibarat power berjenis ocl output memakai kaki transistor emictor dan yang satunya output dihandel ke ground aktif pada travo 1 ampereCT.

Travo 5 ampere engkel tegangan tinggi menghendel mulai tingkatan sistem buffer transistor, penguat buffer transistor, dan vinal transistor output, driver power amplifier yang bersumber output positif ke speaker yang kerjanya memaksimalkan tenaga yang dihasilkan oleh power amplifier berbasis ground bridge, sedangkan power amplifier yang satunya hanya bekerja sebagai pengoptimalan ground aktif pada speaker negatif, disitu hanya memakai input balikan dari output speaker positif yang diolah di driver power amplifier ground aktif tersebut, mengombinasi sebuah tegangan yang mempengarui titik sumber osilator ic yang bergerak mengkover sistem ground aktif pada power amplifier tersebut.

\section{Penghitungan daya kombinasi trafo 1 ampere ct dan 5 ampere engkel untuk power amplifier class $\boldsymbol{G B}$}

a. 5 ampere engkel dengan tegangan $35.2=70$ volt

$$
\begin{aligned}
& \mathrm{P}=\mathrm{V} . \mathrm{I} \\
& \mathrm{P}=70.5 \mathrm{~A} \\
& \mathrm{P}=350 \text { watt }
\end{aligned}
$$

b. 1 ampere ct maksimum peak 15 volt

$$
\begin{aligned}
& \mathrm{P}=\mathrm{V} . \mathrm{I} \\
& \mathrm{P}=15.1 \\
& \mathrm{P}=15 \text { watt }
\end{aligned}
$$

Jadi daya maksimal yang bisa dikeluarkan dari trafo tersebut adalah $350+15=\mathbf{3 6 5}$ watt untuk mensuplai power amplifier class $G B$. Yang sudah diketahui bahwa power ini menggunakan empat pasang transistor final dimana tiap pasangnya memiliki maksimum daya 400 watt

Perhitungan trafo 5A CT daya yang harus dikeluarkan untuk power amplifier BTL sebagai pembanding daya power amplifier class $G B$

Dengan sama sama menggunakan transistor final empat pasang 400 watt. Ada dua model penggunaan trafo pada power amplifier BTL.

1. Menggunakan satu trafo 5 ampere ct untuk mensuplai dua titik amplifier, maksimum peak 35 volt, jadi

$$
\begin{aligned}
& \mathrm{P}=\mathrm{V} . \mathrm{I} \\
& \mathrm{P}=35.5 \\
& \mathrm{P}=175 \text { watt }
\end{aligned}
$$

2. menggunakan dua trafo untuk mensuplai dua rangkaian power amplifier pada dua titik yang berbeda. seperti contoh menggunakan 2 buah trafo 5 ampere ct dimana daya trafo maksimum peaknya adalah 35 volt, jadi

$\mathrm{P}=\mathrm{V}$. I

$\mathrm{P}=35.5$

$\mathrm{P}=175$ watt

Dari hasil diatas dikalikan 2 untuk mensuplai masing masing titik amplifier yakni 175 x $2=350$ watt

\section{Penghitungan Daya power amplifier GB}

$\mathrm{P}=\mathrm{V}$. I

dimana,

$\mathrm{P}=$ daya $(\mathrm{VA} / \mathrm{Watt})$

$\mathrm{V}=$ Voltase $/$ Tegangan $($ Volt $)$

$\mathrm{I}=$ Arus (Ampere)

$\mathrm{Vdc}=\mathrm{Vac} \times 1,414(1,414$ merupakan satuan standar)

$\mathrm{Vdc}=70 \mathrm{Vac} \mathrm{X} 1,414$

$\mathrm{Vdc}=98,98 \mathrm{Vdc}$

Maka

$\mathrm{P}=\mathrm{V}$. I

$\mathrm{P}=98,98 \mathrm{Vdc} X 5 \mathrm{~A}$

$\mathrm{P}=494,9 \mathrm{VA} /$ WattTrafo $5 \mathrm{~A} \times 70 \mathrm{Vac}(98,98 \mathrm{Vdc})$ mampu menghasilkan daya sekitar 494,9

VA/Watt

Tegangan out powersupply trafo 5 ampere engkel yang sudah diketahui 68,8 
$\mathrm{P}=\left(\mathrm{VRMS}^{\wedge} 2\right) / \mathrm{R}$

$\mathrm{P}(8 \mathrm{ohm})=68,6 \wedge 2 / 2 \times 8=294,1225$ cara menghitungnya, 68,6 kuadrat sama dengan 68,6 x68,6 = 4705,96 dan2 x 8 ohm , jadi 9797,04/16 =294,1225 Watt, dibulatkan 294 watt.

$\mathrm{P}(4 \mathrm{ohm})=68,6^{\wedge} 2 / 2 \times 4=588,245$ Watt , cara menghitungnya, 68,6 kuadrat sama dengan 68,6 $\mathrm{x} 68,6=4705,96$ dan $2 \mathrm{X} 4 \mathrm{ohm}$, jadi 9797,04 / 8 $=588,245$ watt, dibulatkan 588 watt.

Apabila Transistor final 100 watt 4 pasang berarti 100 x $4=400$ wattmaximum power amplifier

\section{Penghitungan Daya power amplifier BTL}

$\mathrm{P}=\mathrm{V}$. I

dimana,

$\mathrm{P}=$ daya $(\mathrm{VA} / \mathrm{Watt})$

$\mathrm{V}=$ Voltase $/$ Tegangan (Volt)

$\mathrm{I}=$ Arus (Ampere)

$\mathrm{Vdc}=\mathrm{Vac} \times 1,414(1,414$ merupakan satuan standar)

$\mathrm{Vdc}=35 \mathrm{Vac} \mathrm{X} 1,414$

$\mathrm{Vdc}=49,49 \mathrm{~V}$

maka

$\mathrm{P}=\mathrm{V} . \mathrm{I}$

$\mathrm{P}=49,49 \mathrm{Vdc} X 5 \mathrm{~A}$

$\mathrm{P}=247,45 \mathrm{VA} /$ WattTrafo 5A x 35Vac

$(49,49 \mathrm{Vdc})$ mampu menghasilkan daya sekitar $247,45 \mathrm{VA} / \mathrm{Watt}$

$35 \mathrm{AC}=49,49 \mathrm{Vdc}$ (setelah melewati diode dan elco) dibulatkan saja menjadi 50 volt. $\mathrm{P}=\left(\mathrm{VRMS}^{\wedge} 2\right) / \mathrm{R}$

$\mathrm{P}(8 \mathrm{ohm})=50^{\wedge} 2 / 2 \times 8=156,25$ Watt, cara menghitungnya, 50 kuadrat sama dengan $50 \times 50$ $=2500$, dan $2 \times 8$ ohm , jadi $2500 / 16=156,25$ watt, dibulatkan 156 watt.

$\mathrm{P}(4 \mathrm{ohm})=50^{\wedge} 2 / 2 \times 4=312,5$ Watt , cara menghitungnya, kuadrat sama dengan 50 X $50=$ 2500, dan 2 X 4 ohm $=8$, jadi $2500 / 8=312,5$ watt, dibulatkan 312 watt.

Apabila Transistor final 100 watt 4 pasang berarti 100 x $4=400$ wattmaximum power amplifier

Dari keterangan diatas maka dapat disimpulkan bahwa kombinasi trafo yang digunakan untuk mensuplai power amplifier class $G B$ ini lebih efisien daya trafonya dibanding menggunakan sistem power amplifier BTL.
Tabel 1. Tegangan trafo off beban suara Trafo $1 \mathrm{~A}$ Trafo 5A

\begin{tabular}{cccc}
\hline $\begin{array}{c}\text { Tegangan } \\
\text { AC input }\end{array}$ & $\begin{array}{c}\text { Tegangan } \\
\text { AC } \\
\text { output }\end{array}$ & $\begin{array}{c}\text { Tegangan } \\
\text { AC input }\end{array}$ & $\begin{array}{c}\text { Tegangan } \\
\text { AC output }\end{array}$ \\
\hline 202,3 & $15,8 \mathrm{Vac}$ & 202,3 & 57,1 Vac \pm \\
Vac \pm & \pm & Vac \pm &
\end{tabular}

Tabel 2 output trafo 1 ampere off beban suara Tegangan output Tegangan output trafo 1A power supply trafo $1 \mathrm{~A}$

\begin{tabular}{ll}
\hline CT ke 18 volt & CT ke positif 14,61 \\
\hline 15,8 Vac \pm & Vdc \\
\hline CT ke 18 volt & CT ke negatif 14,63 \\
\hline 15,8 Vac \pm & Vdc
\end{tabular}

Tabel 3 Tegangan powersupply travo 5 ampere off beban suara

Tegangan output trafo Tegangan outputpower supply trafo $5 \mathrm{~A}$ $55,8 \mathrm{Vac} \quad 68,6 \mathrm{Vdc}$

Tabel 4 Tegangan on beban suara travo 1A dan 5A

Trafo 1A Trafo 5A

Tegangan Tegangan Tegangan Tegangan

\begin{tabular}{llll} 
AC input & AC output & AC input & AC output \\
\hline $202,3 \mathrm{Vac}$ & $15,0 \mathrm{Vac}$ & $202,3 \mathrm{Vac}$ & $30,9 \mathrm{Vac}$
\end{tabular}

$\pm \quad \pm \quad \pm \quad \pm$

Tabel 5 Tegangan powersupply 1 ampere on beban suara

Tegangan output trafo Tegangan output 1A power supply trafo 1A

\begin{tabular}{cc}
\hline CT ke out 18 & CT ke positif 14,5 Vdc \\
\cline { 1 - 1 } 15,8 Vac \pm & CT ke negatif $14,5 \mathrm{Vdc}$
\end{tabular}

Tabel 6 Tegangan travo 5A

Tegangan output

Tegangan trafo $5 \mathrm{~A}$ outputpowersupply $55,8 \mathrm{Vac}$ $32,7 \mathrm{Vdc}$

Tabel 7 Pengukuran transistor final off beban suara

Tegangan Tegangan Tegangan input kaki input kaki input kaki colector colector basis final C5198 transistor transistor

\begin{tabular}{ccc} 
& A1941 & C5198 \\
\hline $70,8 \mathrm{Vdc}$ & $70,8 \mathrm{Vdc}$ & $+19 \mathrm{Vdc}$
\end{tabular}


Tabel 8 pengukuran transistor final off beban suara

\begin{tabular}{lll}
$\begin{array}{l}\text { Tegangan } \\
\text { input kaki }\end{array}$ & $\begin{array}{l}\text { Tegangan } \\
\text { output power }\end{array}$ & $\begin{array}{l}\text { Tegangan } \\
\text { output } \text { power }\end{array}$ \\
basis transistor & A transistor & B transistor \\
C5198 & final & final \\
\hline - 19 Vdc & $00,00 \mathrm{Vdc}$ & $00,00 \mathrm{Vdc}$
\end{tabular}

Tabel 9 Pengukuran transistor final on beban suara

\begin{tabular}{|c|c|c|}
\hline $\begin{array}{c}\text { Tegangan } \\
\text { input kaki } \\
\text { colector } \\
\text { transistor } \\
\text { C5198 }\end{array}$ & $\begin{array}{c}\text { Tegangan } \\
\text { input kaki } \\
\text { colector } \\
\text { transistor } \\
\text { A1941 }\end{array}$ & $\begin{array}{c}\text { Tegangan } \\
\text { input kaki } \\
\text { basis final } \\
\text { transistor } \\
\text { C5198 }\end{array}$ \\
\hline $49,9 \mathrm{Vdc}$ & $49,9 \mathrm{Vdc}$ & $00,34 \mathrm{Vdc}$ \\
\hline \multicolumn{3}{|c|}{$\begin{array}{l}\text { Tabel } 10 \text { Pengukuran transistor final on } \\
\text { beban suara }\end{array}$} \\
\hline $\begin{array}{l}\text { Tegangan } \\
\text { input kaki }\end{array}$ & $\begin{array}{l}\text { Tegangan } \\
\text { output power }\end{array}$ & $\begin{array}{c}\text { Tegangan } \\
\text { output } \text { power }\end{array}$ \\
\hline $\begin{array}{l}\text { basis transistor } \\
\text { A1941 }\end{array}$ & $\begin{array}{l}\text { A transistor } \\
\text { final }\end{array}$ & $\begin{array}{l}\text { B transistor } \\
\text { final }\end{array}$ \\
\hline $00,39 \mathrm{Vdc}$ & $6,7 \mathrm{Vac}$ & $00,00 \mathrm{AC}$ \\
\hline
\end{tabular}

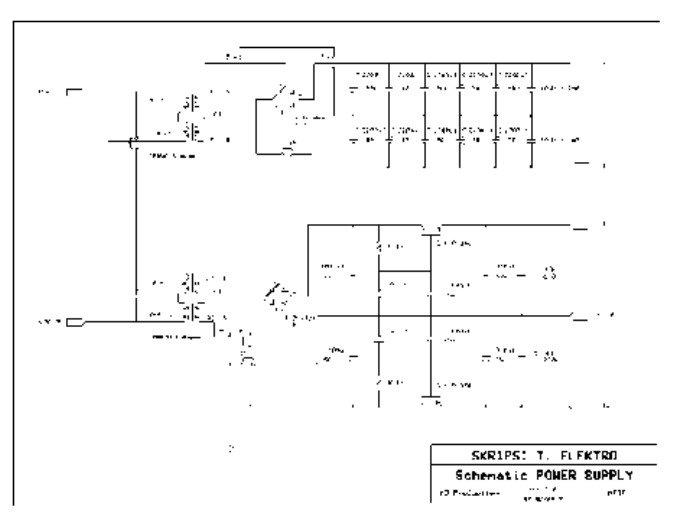

Gambar 1 skema power supply

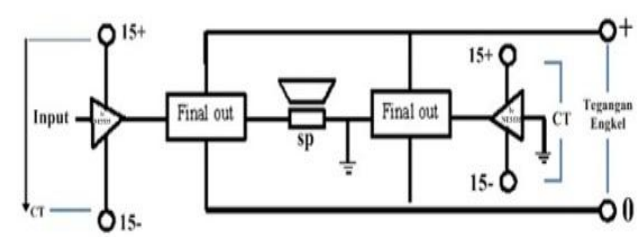

Gambar 2 skema power amplifier class $G B$

\section{KESIMPULAN}

Rangkaian power amplifier class $G B$ ini bisa diterapkan pada audio lokal pada skema rangkaian power amplifier umum ditemui dipasaran lokal, yang membedakan adalah jenis komponen serta kombinasi trafo yang digunakan yang bisa dianggap efektif diterapkan pada rangkaian poweramplifier tersebut.

Sistem kerja trafo dan power amplifier hampir sama tapi berbeda dengan jenis rangkaian power amplifier bridge (BTL) yang mana pada rangkaian power amplifier bridge(BTL) menggunakan dua output $P A$ untuk melipat gandakan daya yang dihasilkan. Sedangkan pada power amplifier class GB sama sama mengeluarkan dua output hanya saja satu dari dua output tersebut di Ground.

input tegangan yang dihasilkan dari power amplifier ini sangat tinggi namun dapat dikover tegangannya dengan dua kombinasi trafo $1 \mathrm{~A}$ ct dan 5A engkel karena power tersebut langsung memainkan tegangan input dengan begitu besar, output suara yang dihasilkan sangat tajam dengan karakter suara yang condong ke low audio.

\section{PUSTAKA}

BSNP.2006. Panduan Penyususan Kurikulum Tingkat Satuan Pendidikan Jenjang Pendidikan Dasar dan Menengah. Jakarta: BSNP

Budiharto, Widodo; \& Firmansyah Sigit. 2010 Elektronika Digital dan mikroprosessor. Yogyakarta.Penerbit Andi.

Durbin,dkk. 2005. RangkaianListrik.Jakarta: Erlangga

Firdaus, Himan. 1996, Elektronika. Bandung: GMP

Grop, Bernard dan Mitchel E. Schultz.2003. Basis Electrinic. $9^{\text {th }}$ Edition. New York :Mc Graw-Hill Companis. Inc.

Ken Session. 1967. IntegratedElectronics. San Fransisco California: Holden Day

Schules, Charles A. 2003. ElekctronicPrinsipleandApplication. New York: Mc Graw-hill Companies. Inc.

Morris, Noel M. 1987. Dasar-dasar Listrik dan Elektronika. Jakarta: Elex Media Komputindo

Lin H.C 1967. Integrated Electronic. San Fransisco California:Holden Day.

Tim Skripsi, 2014 Pedoman Penulisan Skripsi. Fakultas Teknik Universitas Islam Lamongan

Rusmadi, Dedy. (1995), Mengenal Komponen Elektronika. Bandung: Pionir jaya

Putra ,Yefri Handoko.2006. Perangkat Pengaturan Elektronik. Bandung: Talita Khoum.

www.HarmanKardon.com 
